Abstracta Iranica Abstracta Iranica

Revue bibliographique pour le domaine irano-aryen

Volume 31 | 2011

Comptes rendus des publications de 2008

«Euclid's Elements, Courtly Patronage and Princely Education ». Iranian Studies, vol. 41, fasc. 4, 2008, p. 441-463.

Rédaction

(2) OpenEdition

Journals

Édition électronique

URL : http://journals.openedition.org/abstractairanica/39743

DOI : 10.4000/abstractairanica.39743

ISSN : 1961-960X

Éditeur :

CNRS (UMR 7528 Mondes iraniens et indiens), Éditions de l'IFRI

Édition imprimée

Date de publication : 15 mai 2011

ISSN : 0240-8910

Référence électronique

Rédaction, « «Euclid's Elements, Courtly Patronage and Princely Education ». Iranian Studies, vol. 41, fasc. 4, 2008, p. 441-463. », Abstracta Iranica [En ligne], Volume 31 | 2011, document 255, mis en ligne le 11 octobre 2012, consulté le 05 octobre 2020. URL : http://journals.openedition.org/ abstractairanica/39743; DOI : https://doi.org/10.4000/abstractairanica.39743

Ce document a été généré automatiquement le 5 octobre 2020.

Tous droits réservés 


\section{« Euclid's Elements, Courtly Patronage and Princely Education ». Iranian Studies, vol. 41, fasc. 4, 2008, p. 441-463.}

\section{Rédaction}

1 Jusqu'au XIV ${ }^{e}$ s., les Éléments d'Euclide était le texte mathématique, faisant l'objet de recherches, le plus important. La traduction persane était liée à la diffusion du texte arabe en Iran, Asie centrale et en Inde, essentiellement dans les milieux de la cour. A partir des Ilkhanides le texte intégral a été progressivement remplacé par des extraits dans les encyclopédies et anthologies, la forme de leur présentation indiquant leur usage

- l'agrément et l'éducation. La partie principale de l'article retrace l'historique du texte, ses sources, versions ("éditions"), interpolations et pratiques qui les accompagnent, depuis les Abbasides jusqu'aux Safavides. Une attention particulière est portée à la fortune du texte chez Avicenne et Jozjānī, à la version de Nașīr al-dīn Ṭūsī et du pseudo-Ṭūsī, aux différentes versions du langage utilisé et aux traits de présentation qui sont spécifiques au contexte islamique. Cet article démontre l'intérêt que représente une étude complète d'un genre textuel en science et la possibilité d'identifier des traces de la science mathématique dans les cours tardives en Iran.

\section{INDEX}

Thèmes : 10. Histoire des Sciences et des Techniques 


\section{AUTEURS}

\section{RÉDACTION}

Directeur de la revue et secrétariats (Paris et Téhéran) 